\section{AN HOUR AT JONES' PEAK}

\section{MARGARET BELCHER, 2601 Winnipeg Street, Regina, Saskatchewan S4P 1H8}

The wedding of Gary Seib and Barpara Shourounis took me to Eastend in a pleasant weekend in June, 1977. Because I had an English visitor as a ompanion, I was also looking orward to doing a little birding in hat interesting country. To our lelight, the bride and groom, in the nidst of the wedding reception but vith complete sang froid, advised bout locations where we might see pecies like the Rock Wren. The next horning, June 19 , we followed their irections and climbed north out of he valley to take the road to Jones' eak, a splendid vantage point for the renchman River Valley. This high utte, now the site of a Sask Tel comhunications tower, is named after the ell known pioneer naturalist and puseum curator Corky Jones.

In the hour that we spent there, in id-morning, we had a generous ample of the bird life of the renchman River Valley's eroded opes. We watched a pair of Mounin Bluebirds, for example, making rany trips with food to what was aparently a nest site behind the andstone outcroppings of the steep utbank. A spot they favoured in their unt for insects was a slight pebbly epression on the hill top, where the rale bluebird, a Rock Wren and hipping Sparrow were all observed king food.

From time to time, we spotted a ock Wren singing from its perch or oving about busily in search of od, while below in the coulees we puld hear the distant voice of a Say's hoebe. A Prairie Falcon also passed ver the coulees below us several mes with its characteristic call, ggesting that it might be nesting on ie of the cliff faces.

At the reservoir near Eastend we ad watched swallows closely, thout seeing Rough-wings, but om the hilltop at Jones' Peak we had excellent view of a pair flying just

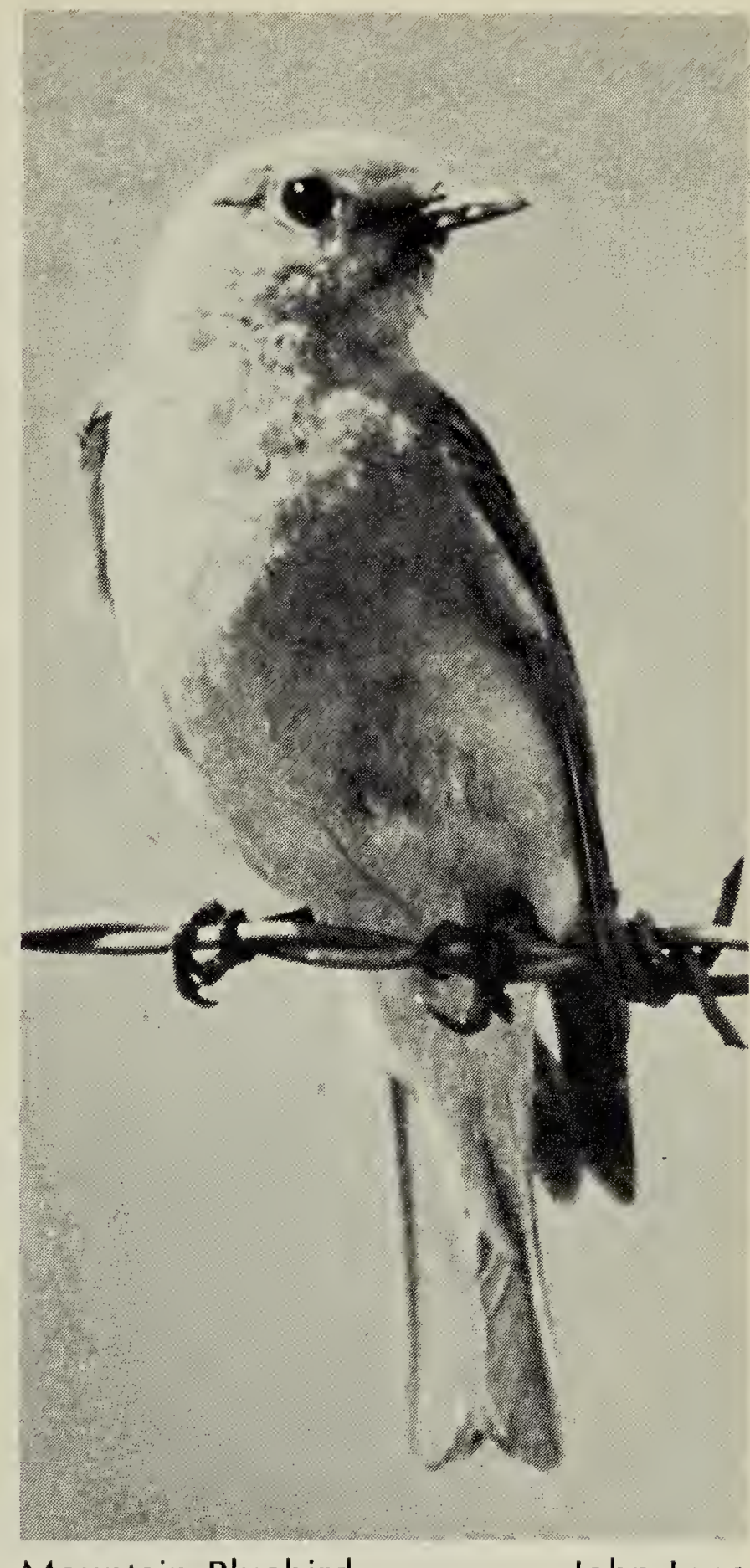

Mountain Bluebird

John Lane

below us. More exciting was a pair of Violet-green Swallows that we were able to watch closely as they flew in and out behind a sandstone outcropping, obviously feeding young. Although this species was not definitely established as breeding in Saskatchewan until a nest was found at the SNHS Prairie Dog Sanctuary near Val Marie during the SNHS summer meeting in June, 1969, sightings had been reported previously along the Frenchman River where the terrain obviously provides a likely habitat for them.

Turning our faces away from the Valley occasionally to look north over farms in the hills, we saw hawks (par- 
ticularly the Ferruginous) and a Golden Eagle. For the birder from England, this short hour of observation from Jones' Peak revealed the characteristic bird life of that dramatic eroded valley terrain.

\section{SAW WHET OWL ATTACKS ROBIN}

SANDRA JOHNS

\#4-14936 56 Avenue,

Edmonton, Alberta T6H 4X9

On April 20, 1977 I was conducting a lonely vigil at a Saw whet Owl nest on the Wagner property, a sprucetamarack bog on 118 Avenue on the outskirts of Edmonton, Alberta. A male Ruffed grouse was drumming close by, a coyote walked in the forest within 20 feet of me, and two robins were singing in the area.

At 2023, while still fairly light, the Saw whet male arrived, calling softly, and sat in a tree 15 feet behind me, directly facing the nest (about 30 feet away). The male transferred prey from foot to beak, flew to the nest, calling softly, and deposited food in the nest hole.

The bird returned to his original perch and called territorially for a few seconds. One of the robins landed in a tree a few feet from the nest, then flew to a tree, 60 feet east of the nest.

Suddenly, the male owl took off from his perch, flew at the singing robin and struck it with his talons. The robin, screeching loudly, flew over me and away from the area. The owl disappeared into the bushes. No robin sang for the rest of the evening. It was a most dramatic incident.

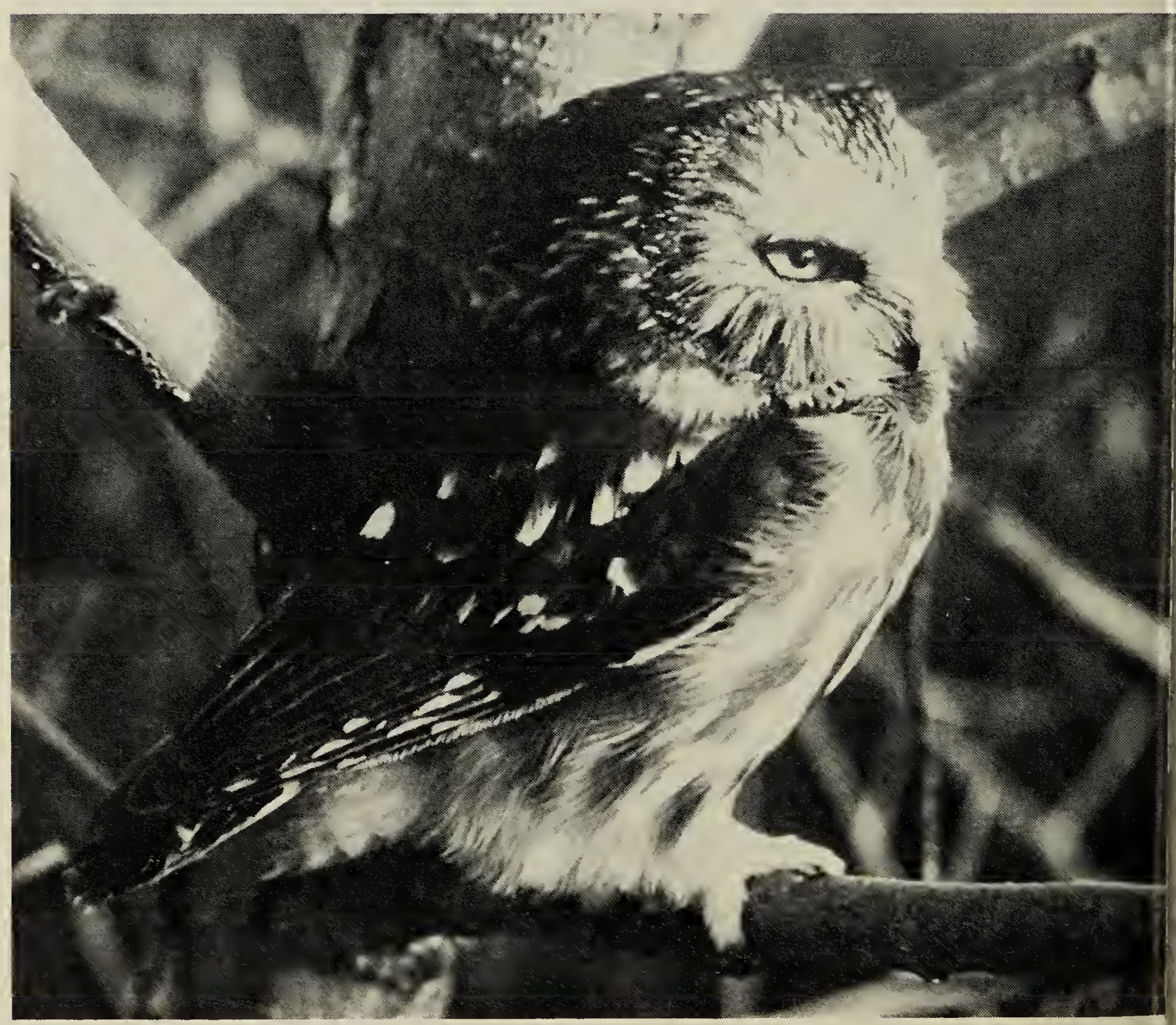

